The Effect of Foreclosures on Crime in Indianapolis, 2003-2008

\author{
Thomas D. Stucky* \\ John R. Ottensmann \\ Seth B. Payton \\ School of Public and Environmental Affairs \\ Indiana University Public Policy Institute \\ Indiana University-Purdue University Indianapolis
}

*Direct all correspondence, including data and coding requests for replication purposes to: Thomas D. Stucky, Ph.D.

BS/SPEA Building 4085

801 W. Michigan St.

Indianapolis, IN 46202

tstucky@iupui.edu.

This is the author's manuscript of the article published in final edited form as:

Stucky, T. D., Ottensmann, J. R., \& Payton, S. B. (2012). The Effect of Foreclosures on Crime in Indianapolis, 2003-2008*. Social Science Quarterly, 93(3), 602-624. http://dx.doi.org/

10.1111/j.1540-6237.2012.00890.x 


\title{
The Effect of Foreclosures on Crime in Indianapolis, 2003-2008
}

Keywords: foreclosures, crime, spatial analysis, ecological theories

\begin{abstract}
Objective: Until recently few studies have examined the relationship between home foreclosures and crime. Foreclosures are one major source of neighborhood instability and can be expected to affect crime from several theoretical perspectives. Some recent research has found conflicting results on whether foreclosures cause crime.

Method: This study examines whether foreclosures are a robust predictor of crime and whether the effect of foreclosures on crime varies across neighborhood contexts. We estimate fixed effects negative binomial models using geocoded Indianapolis foreclosure and crime data for 2003 to 2008 to predict crime counts in 1,000-feet X 1,000-feet square grid cells.

Result: Foreclosures exhibit consistent positive effects on indices of overall, property, and violent UCR reported offenses in a cell and rape, aggravated assault, and burglary counts. In addition, foreclosures had greater effects on reported UCR crimes in stable neighborhoods, especially those with more owner-occupied homes.

Conclusion: Foreclosures were a robust predictor of crime in the current study.
\end{abstract}




\section{INTRODUCTION}

The growth in the number of foreclosures that resulted from the recent housing crisis in America has brought considerable attention to the detrimental effects of foreclosures on neighborhood instability. Criminological research has focused on the role of neighborhood stability since at least the days of Shaw and McKay (1972). A large body of housing research suggests that foreclosures are detrimental to the stability of neighborhoods ${ }^{1}$. Yet, until recently, little research has examined the relationship between foreclosures and crime.

As will be outlined below, there are several theoretical reasons why one might expect foreclosures to increase crime. Routine activities, social disorganization, rational choice and even general strain theories all predict that foreclosures and crime would be related. From the standpoint of routine activities theory, foreclosures might be associated with increased crime due to increased prevalence of vacant or abandoned properties, which are less likely to have adequate guardianship and present easier targets for crime. Social disorganization theory predicts that foreclosures would increase crime by increasing residential mobility, which would likely reduce social cohesion and community ties, and reduce informal social control. So there are a variety of reasons to expect foreclosures to be associated with higher crime.

Several recent studies have examined foreclosures and crime (e.g., Bess, 2008; Cui, 2011; Goodstein \& Lee, 2010; Harris, 2011; Immergluck \& Smith, 2006b; Kirk \& Hyra, 2011). Some of these studies were cross sectional (Acevedo, 2009; Immergluck \& Smith, 2006b) limiting the ability to discern causation. Others were longitudinal studies but included fairly large units of analysis such as counties (Goodstein \& Lee, 2010), census tracts (Kirk \& Hyra, 2011), or police beats (Harris,

\footnotetext{
${ }^{1}$ Scholars not only have examined the discount price of foreclosed home sales (Crawford \& Rosenblatt, 1995; Pennington-Cross, 2006), but also the external costs and societal impacts of concentrated home foreclosures on neighborhoods. For instance, foreclosures have been found to have a negative effect on the value of surrounding properties (Immergluck \& Smith, 2006a; Schuetz, Been, \& Ellen, 2008; Harding, Rosenblatt, \& Yao 2009; Lin, Rosenblatt, \& Yao, 2009) and diminish revenues and increase costs for local governments (Moreno, 1995, Apgar \& Duda, 2005).
} 
2011). We are aware of only two studies (Cui, 2011; Ellen, Lacoe, \& Sharygin, 2011) that employ units of analysis smaller than a census tract. We argue that small units of analysis are likely critical for capturing the impact of foreclosures on crime, which is expected to be limited to a fairly small geographic area.

The current study explores whether there is an independent effect of foreclosures on crime, and whether this effect is conditioned by neighborhood characteristics, using panel models and a small unit of analysis. Specifically, we estimate fixed effects negative binomial models of foreclosures on Uniform Crime Reports (UCR) crime counts in 1,000-feet X 1,000-feet square grid cells in Indianapolis, Indiana, from 2003 to 2008.

\section{FORECLOSURES AND CRIME}

Several criminological perspectives have been used to motivate discussions of why one would expect foreclosures to be associated with crime. Routine activities theory suggests that crime is more likely when crime targets and potential offenders come into contact in the absence of a capable guardian (Cohen \& Felson, 1979). Foreclosed homes are less likely to be monitored especially when vacant, which presents a greater likelihood that these homes will be perceived as suitable targets by would-be offenders (see Ellen et al., 2011). Research by Spelman (1993) showed that abandoned homes were associated with higher crime.

Others have suggested that social disorganization is a useful framework for thinking about how foreclosures might affect crime (e.g., Harris, 2011; Pandit, 2011). Social disorganization theory states that community social structural factors such as residential mobility, socioeconomic disadvantage, family instability, and ethnic heterogeneity reduce the capacity for neighborhood residents to maintain informal social control, leading to higher crime (see Sampson \& Groves, 1989). ${ }^{2}$ Residential mobility has long been thought to reduce neighborhood social organization.

\footnotetext{
${ }^{2}$ Recent work in this area refers to the ability or willingness to intervene in neighborhood affairs to maintain social control as “collective efficacy” based on Sampson and colleagues' (1997, 1999, 2004) revamping of the traditional
} 
When residents regularly move in and out of a neighborhood, it is harder for people to get to know their neighbors and develop and maintain the social ties necessary to create effective informal social control. One recent study by Xie and McDowall (2008) found that neighborhood residential turnover was associated with increased victimization. Foreclosures are expected to increase residential mobility and reduce ties among neighbors (Harris, 2011, p. 24). Other structural elements of social disorganization—ethnic/racial heterogeneity and family disruption—-have also recently been found to be associated with higher foreclosure rates (Li \& Morrow-Jones, 2010). Thus, from a social disorganization perspective, one would expect foreclosures and crime to be related.

Another theory of crime, the so-called "broken windows" theory, focuses on how neighborhood physical disorder (e.g., visible litter, broken vehicle or home windows) creates the impression that residents don’t care much about their neighborhood and signals to would-be criminals that the neighborhood presents a likely target. Over time, signs of physical disorder can create a downward spiral for neighborhoods, reduce perceptions of neighborhood safety, and lead to higher rates of serious crime (Wilson \& Kelling, 1982). Pandit (2011) argues that foreclosed homes tend to be less well-maintained, especially after vacancy. Such visible evidence of neglect could signal to would-be criminals that a neighborhood presents an easier target. Others have argued that rational choice (Ellen et al., 2011) or general strain theories (Harris, 2011) would predict foreclosures to be associated with increased crime. Thus, it is clear that there are good reasons to expect foreclosures and crime to be related from a variety of theoretical perspectives.

It is also reasonable to consider whether foreclosures would affect crime similarly across all neighborhood contexts. For example, Harris (2011, p. 44) argues that disadvantage and population density will condition the relationship between foreclosures and crime. Foreclosures in

social disorganization framework. Although perhaps a bit of an oversimplification, one might think of collective efficacy as the mirror image of social disorganization. For the purposes of this paper, foreclosures would be expected to lead to crime through low collective effective efficacy or high social disorganization. For a discussion of foreclosures and collective efficacy see Pandit (2011). 
disadvantaged areas might further weaken fragile informal social networks. Disadvantaged neighborhoods may also be likely to have more renters and fewer stable residents. Thus, a foreclosure may be especially damaging as it represents the loss of an uncommon asset in disadvantaged neighborhoods, a stable homeowner. Or, it could be that foreclosures have less of an effect on crime in disadvantaged neighborhoods because they already suffer from instability and any additional instability caused by foreclosures would not materially alter the neighborhood social fabric as much as in more stable, advantaged neighborhoods. Therefore, the current study will examine both whether there is an effect of foreclosures on crime and whether this effect is conditioned by other neighborhood characteristics such as socioeconomic disadvantage and residential stability.

\section{PRIOR RESEARCH}

As noted, nearly all studies of foreclosures and crime have been undertaken since 2006. The first major study was Immergluck and Smith’s (2006b) cross-sectional study of Chicago census tracts. They found that the foreclosure rate affected violent crime but not property crime. Acevedo (2009) studied 32 Atlanta census tracts and found that foreclosures were significantly related to property crime increases but not violent crime. Teasdale, Clark, and Hinkle (2010) studied 71 Akron census tracts in 2003. Using negative binomial models and controlling for prior crime, they found a significant effect of foreclosures on counts of larceny, burglary, drugs, and disorderly conduct, individually and cumulatively. ${ }^{3}$ Baumer, Wolff, and Arnio (2011) examined the link between foreclosures and crime in 1,507 U.S. counties in 2007 using negative binomial models and controlling for spatial autocorrelation. They found significant effects of foreclosure on crime but the effects depended on unemployment, levels of new home construction, and resource deprivation.

\footnotetext{
${ }^{3}$ Bess (2008) examined trends in crime in Charlotte- Mecklenburg from 2003 to 2006. The study found that violent crime incidents per 100 households were generally higher in high foreclosure neighborhoods than in low foreclosure neighborhoods. This study, however, did not estimate multivariate models or include controls for other neighborhood characteristics.
} 
Several recent studies of foreclosures and crime have employed panel models. Some used large units of analysis such as counties or metropolitan statistical areas (MSAs). Goodstein and Lee (2010) used an instrumental variables approach in their county-level analysis of reported crime from 2002 to 2007, finding that foreclosures increased total violent and property crimes as well as burglary, larceny, and aggravated assault. Foreclosures did not affect rape, robbery, or motor vehicle theft as individual outcomes. Similarly, Pandit (2011) estimated changes in crime from 2005 to 2008 in relation to foreclosures for 225 MSAs with 100,000 or more residents and found that foreclosures were not significantly related to change in violent crime but were marginally significantly $(\mathrm{p}<.10)$ related to changes in property and total crime. ${ }^{4}$

A few panel studies have considered units of analysis smaller than counties or MSAs. Kirk and Hyra (2010) studied violent and property crime rate per 1,000 residents in Chicago census tracts from 2002 to 2008. Given that current community crime rates are heavily influenced by prior crime rates, they employed an Arellano-Bond estimator which allows one to control for lags of the dependent variable and eliminate the influence of unobserved time-invariant differences between communities. Results showed that the cross-sectional association between foreclosure and both property crime and violent crime rates disappeared once one accounted for time-invariant confounding influences and simultaneity. Harris (2011) also used Arellano-Bond models to estimate dynamic panel models of logged crime rates in 108 Houston police beats from 2005 to 2008. Harris (2011) found that foreclosures had positive statistically significant effects on total crime and aggravated assaults in the dynamic panel models. There was no effect of foreclosures on theft, or burglary and a statistically significant negative effect of foreclosures on homicide and auto theft.

\footnotetext{
${ }^{4}$ In a somewhat different kind of analysis, Jones and Pridemore (2011) examined whether the housing crisis affected crime rates in a weighted least squares analysis of 142 MSAs using the housing mortgage stress index (HMSI). The authors found no effect of the HMSI on any of the crimes they tested. This study, however, is not a direct test of the effect of individual foreclosures on crime but an examination of whether the large amounts of stress in the housing market created when the housing bubble burst affected crime.
} 
Harris also found that there was a statistically significant interaction between socioeconomic disadvantage and foreclosures and total crime counts but no other interactions were significant.

We are only aware of two panel studies that use units of analysis smaller than census tracts or police beats. Cui (2011) used a difference in difference approach to examine crime in the areas immediately surrounding foreclosed homes in Pittsburgh from 2005 to 2009. Cui (2011) compared the 250 feet radius circle immediately surrounding a foreclosed home $(\mathrm{N}=3,282)$ with a ring of equal geographic area immediately surrounding the inner ring $(\mathrm{N}=3,282)$, which is intended to serve as a control because it has extremely similar characteristics to the treatment area. Cui (2011) found that foreclosure did not exert a significant effect on crime in the treatment area until the foreclosed home became vacant and found that the effect of vacant foreclosed homes was stronger for violent than property crime. Although this study design is unique, it is possible that the effect of foreclosures extends beyond the 250 feet radius used in the study. If so, the effect of foreclosures on crime could be attenuated because some of the "treatment" effect would be attributed to the comparison area. In addition, if there are several foreclosures in close proximity—a high probability in some neighborhoods - it would seem necessary to exclude those cases and the effects of multiple, clustered foreclosures on crime may be the most significant to consider.

Finally, Ellen, Lacoe, and Sharygin (2011) studied the effects of foreclosures on crime in New York City face blocks from 2004 to 2008. Using a modification of a fixed effect negative binomial model discussed below, the authors found that foreclosures were associated with higher crime rates. Ellen et al. (2011) found that the effects of foreclosures on violent and public order offenses were stronger than the effect on property offenses. They also found evidence that foreclosures caused crime rather than the reverse. This study, however, focuses on New York City which has a very large number of multi-unit properties in the areas where the foreclosures are located (see Ellen et al., 2011, table 2) and so may not be typical of other cities where relatively more foreclosures are in areas with higher proportions of single-family dwellings. 
In sum, only recently have studies empirically examined whether there is a connection between foreclosure and crime, with mixed results. Of the several studies within the last five years, only four are longitudinal and include units of analysis smaller than a county or MSA. Of these studies, two (Harris, 2011; Kirk \& Hyra, 2011) employ fairly large units of analysis such as census tracts or police beats. Unfortunately, census tracts tend to be fairly large and can vary tremendously in size. ${ }^{5}$ Because few panel studies of foreclosures and crime have employed small units of analysis and studies have shown conflicting results, we argue additional research is needed. In the next section, we discuss the data and methods used in the current study.

\section{DATA AND METHODS}

The primary data for this study include number of crimes reported by the Indianapolis Police Department (IPD) and foreclosures listings from the Marion County Indianapolis Board of Realtors (MIBOR) from 2003 to 2008. The counts for number of crimes and foreclosures were calculated for 2,414 1,000-feet X 1,000-feet grid cells within the former Indianapolis Police Department service area. ${ }^{6}$ Socioeconomic variables were collected from the 2000 census at the block and block group level and were estimated for each grid cell.

\section{$\underline{\text { Unit of Analysis }}$}

The units of analysis for this study are 1,000-feet X 1,000-feet square grid cells overlaid on the IPD service area. Grid cells were chosen as the units of analysis as opposed to other possible units for the following reasons. Census tracts and block groups, frequently used for these types of analysis, vary greatly in size. This is known as the modifiable areal unit problem. To the extent that

\footnotetext{
${ }^{5}$ For example, in Indianapolis, census tracts range from 127 acres to 2,440 acres (mean $=536$ acres). The relatively small number of police beats $(\mathrm{N}=108)$ in Harris's (2011) study of Houston suggests that this is also a fairly large unit of analysis.

${ }^{6}$ In 1970, the Indianapolis city government consolidated with Marion County government. Police districts, fire districts, and school districts were not among the local service districts that were included in the 1970 consolidation. The former city of Indianapolis boundaries essentially comprised the Indianapolis Police District until 2008 when IPD consolidated with the Marion County Sheriff's Department.
} 
the effect of foreclosures on crime depends upon distance, use of tracts or block groups introduces bias into the analysis. ${ }^{7}$ The problem is further exacerbated as population characteristics are related to population densities and hence the sizes of these units. Blocks also pose a problem given that reported crimes are often geocoded to street centerlines or intersections and are not uniquely associated with individual blocks, making it difficult to identify the number of crimes associated with each block. Block faces reduce but do not eliminate the problem of associating crimes with the units of analysis. Crimes within a block face are associated with that block face. But significant numbers of crimes are geocoded to intersections, which could be allocated to more than one intersecting block face (as Ellen et al., 2011 did). In addition, it does not seem reasonable that a foreclosure that may have occurred across the street from a property would have a greater effect on crime at that property than a foreclosure to a property immediately adjacent to the back of that property. For these reasons, uniform grid cells are used as the units of analysis (see also Authors 2009). These units also possess the advantage that they provide a natural basis for considering the effects of foreclosures in nearby grid cells. Map 1 illustrates the city of Indianapolis, the IPD service area, and the 1,000-feet X 1,000feet grid cells used in the current analyses.

Map 1 about here

The initial dataset consisted of observations for each year from 2003 through 2008 for 2,225 grid cells that were completely contained within the IPD service area, for a total of 13,350 observations. Grid cells with some portion of their area outside the IPD service area were excluded because some crimes would not have been reported to IPD. We limited the analysis to cells with a population count greater than zero; demographic data discussed below could not be calculated for some cells. Excluding these cells reduced the sample size by 12.3 percent from 13,350 to 11,712 $(1,952 * 6)$

\footnotetext{
${ }^{7}$ The modifiable areal unit problem (MAUP) occurs when point level data are aggregated to arbitrarily, geographically zonal, modifiable boundaries. The bias may occur as non-uniform boundaries are modified. For this reason, this study employs uniform grid boundaries over the study area.
} 


\section{Dependent Variables}

The crime data are geocoded, point data on individual Uniform Crime Report crimes obtained from IPD for the years 2003 through 2008. ${ }^{8}$ We examine total, violent, and property crime counts, as well as individual crime counts for homicide, rape, robbery, aggravated assault, burglary, larceny, and motor vehicle theft. For each outcome variable, the number of incidents per cell in each year was determined.

\section{$\underline{\text { Foreclosure Data }}$}

The foreclosure data are geocoded point data for properties listed for sale and properties sold from the multiple listing service (MLS) database operated by MIBOR. MIBOR estimates that approximately 80 percent of single-family home sales are recorded in the MLS. Listings and sales are considered to be foreclosures when the property listing indicates that the property was either bankowned or HUD-owned. The variables are the counts of the numbers for foreclosure listings and sales that occurred in each grid cell and year. ${ }^{9}$ Finally, given that some grid cells had relatively high numbers of foreclosures, it seemed reasonable to consider the log transforms of these variables.

Several variables measuring foreclosures could be used in predicting crime in the analyses. Our starting point was the number of foreclosure listings and sales in each grid cell. Because foreclosures in the area around a cell could affect crime in a grid cell, we also considered the numbers of foreclosure listings and sales in the 3x3 grid cell neighborhood surrounding each grid cell. Preliminary analyses considered cell foreclosure listing and sales in the cell as well as foreclosure listings and sales in the instant cell and surrounding 8 grid cells. The performance of

\footnotetext{
${ }^{8}$ Geocoding was accomplished using address information, so that crimes could be located as accurately as the nearest street address. Although the specific geocoding success rate was not provided by IPD, the dataset included a few records (less than 1 percent) with no geocoding information. Thus, one could infer that the geocoding success rate exceeded 99 percent. Such a success rate may be possible because IPD uses the same street database that is used by the 911 dispatchers. This is an extremely comprehensive and accurate database, which would contribute to a very high geocoding success rate. IPD also has full-time personnel engaged in "cleaning" the UCR dataset. These factors suggest attention to including accurate address information that could make the high geocoding success rate plausible.

${ }^{9}$ Note that a property could be listed in more than one year before it was sold or withdrawn from sale.
} 
these different variables was examined using each to predict the total crime in the grid cells using the fixed effects negative binomial regression technique discussed below. The log of the number of foreclosure listings in the 3x3 neighborhood was the best predictor of total crime. Therefore, this measure of foreclosures was used in all of the reported analyses.

\section{$\underline{\text { Socioeconomic Variables }}$}

To determine whether foreclosures affect crime (and whether the effect varies across socioeconomic contexts), it is necessary to include relevant socioeconomic predictors of crime. Therefore, we used 2000 census data to estimate values for the socioeconomic characteristics of the grid cells. Variables estimated from the census block data include population, percent AfricanAmerican, percent Hispanic, percent households with children with female householder, and percent occupied housing units owner-occupied. Variables estimated from the census block group data include percent of population foreign-born, percent of persons living in the same residence five years ago, percent of persons in the labor force unemployed, percent of persons with incomes below the poverty level, and median household income. Values for the grid cells were estimated by assuming that the persons, households, or housing units were uniformly distributed within the block or block group. The grid cells were intersected with the block and block group boundaries to determine the proportion of the area of each block and block group within each grid cell. These values were used to estimate the values of the variables for each grid cell.

Numerous prior studies have shown that social structural crime predictors are often highly correlated (e.g., Land, McCall, \& Cohen, 1990; Parker \& McCall, 1999). Therefore, we used principal components analyses to create a disadvantage index, consisting of percent unemployed, percent poor, percent female-headed households, and median income. Factor loadings ranged from 0.68 to 0.83 . As noted above, residential mobility may also create difficulties in maintaining informal social control (see Harris, 2011). Using principle components analysis, we created a stability index, which consisted of the percent of the population that had not moved for five years, the percent of 
residents who are foreign-born, and the percent of owner-occupied houses. Factor loadings on this index ranged from $0.66-0.82$. We also controlled for the percentage of the population that is African American and the percentage Hispanic in the cell. Finally, because more population in a cell might contribute to higher crime counts, we also controlled for the cell population.

\section{Modeling Strategy}

The dataset is a panel dataset with 1,952 cases by six years. This allows analysis using a fixed effects model that holds constant the effects of those grid cell characteristics that do not vary over time. The fixed effects model allows for stronger inference that the effect of foreclosure on crime is not the result of the association of foreclosures with other neighborhood characteristics that in turn affect crime. Use of the fixed effects model cannot guarantee that the effect of crime on foreclosure is a causal relationship as the possibility exists that there are other time-varying characteristics of the grid cells associated with both foreclosures and crime. However, the use of the fixed effects model permits much stronger inference than models that control for other neighborhood characteristics by including these as control variables, as one can never know that all relevant characteristics are being controlled for.

The dependent variable in the models is the count of the number of crimes that occurred in each grid cell in each year. Because these are counts, their distribution is not normal, and the linear fixed effects model is not appropriate. The numbers of zero counts create over-dispersion in a Poisson model. Therefore, the fixed effects negative binomial (FENB) model is appropriate for estimating the relationship between crime and foreclosures (see Greene, 2000; Osgood, 2000, Osgood \& Chambers, 2000). We used the procedure xtnbreg in Stata to estimate the FENB model (StataCorp, 2009). This procedure uses the method developed by Hausmann, Hall, and Griliches (1984) and described in Cameron and Trivedi (1998). Allison and Waterman (2002) have identified some problems with this procedure but were not able to produce a clearly superior alternative. 
Allison (2005) suggests an alternative method of estimation that is used by Ellen et al. (2011). This is discussed more fully below in the section on alternative tests of robustness.

\section{RESULTS}

\section{Descriptive Statistics}

We begin with basic descriptive statistics for all of the variables used in the analyses. Table 1 shows the means, standard deviations, and ranges of the variables used in the analyses. Total cell crime counts averaged 18.03 per cell with a range of zero to 270. Foreclosure listings ranged from zero to 47 with an average of 1.43 . Foreclosure sales ranged from zero to 22 with an average of 0.81 .

Table 1 about here

Table 2 shows average cell crime counts and foreclosure listings by year. In general, crime counts and foreclosures increased each year from 2003 to 2007, but declined a bit in 2008.

Table 2 about here

Table 3 shows the mean crime counts (total UCR crime) by the number of foreclosure listings. The table clearly shows that crime in the cell steadily increases as the number of foreclosures increases. For example, the mean crime count per cell in cells with three foreclosures was more than twice that of cells with zero foreclosures (25.1 v. 12.8). Thus, examination of basic statistical evidence in the current data is consistent with the idea that more crime is associated with more foreclosure listings. Of course, Table 3 does not control for a number of other factors that might also drive crime counts.

Table 3 about here

\section{Analysis of Direction of Causation}

Estimation of the effects of foreclosures on crime poses the potential issue of endogeneity. Although the levels of foreclosures in an area may cause changes in the levels of crime, levels of crime may also affect the numbers of foreclosures. This could occur if homeowners in areas with 
high crime were more likely to stop payment and default because of the level of crime, or if mortgage holders of properties in high crime areas were more likely to foreclose (or to foreclose more quickly) because of perceived risk to the properties. To examine this, we follow the example of Hipp, Tita, and Greenbaum (2009) in examining the directionality of the causal relationships between crime and residential instability. Crime in a given year could be caused by foreclosures in the preceding year (lagged foreclosures), while the prior level of foreclosures cannot be caused by current crime. Likewise, foreclosures could be caused by lagged crime, but lagged crime could not be affected by current foreclosures.

We therefore estimate FENB models regressing total crime on lagged foreclosure listings and regressing foreclosure listings on lagged crime. As is usual in estimating panel models, we include year dummy variables to account for temporal changes. ${ }^{10}$ In the first model, the lagged foreclosure variable is a significant predictor of total crime counts. In the second, lagged total crimes variable is not a significant predictor of foreclosures. These results strongly suggest that the relationship is one of foreclosures causing crime and not the reverse, reducing the likelihood of endogeneity issues.

Table 4 about here

\section{Effects of Current and Lagged Foreclosures on Total Crimes}

Turning to the major questions of the study, we first discuss analyses of the effects of the current and lagged values of the log of neighborhood foreclosure listings on total crime. We ran models using the current value of the log of neighborhood foreclosure listings, the lagged value, and both, which are shown in Table 5. All models are restricted to the years 2004 to 2008 so analyses are being compared on comparable cases. ${ }^{11}$ Comparing the first and second models in Table 5, both the current and lagged foreclosure variables are significant, but the coefficient for the lagged value is over twice as large, with essentially the same standard error. When both the current and lagged

\footnotetext{
${ }^{10}$ Note that the number of cases can vary as cases were dropped when they had all zero outcomes.

${ }^{11}$ Models with additional lags are not considered as they would result in the loss of too many cases.
} 
foreclosure measures are included (the third model), current foreclosures are no longer significant. Therefore, although there is evidence that both current and prior foreclosures are associated with total crime counts, the lag of the log of neighborhood foreclosure listings is used in subsequent models.

\section{Table 5 about here}

\section{Effects of Foreclosures on Types of Crimes}

Table 6 shows the effects of the foreclosure listing variable on total, violent, and property crime counts in the cell. Foreclosures are a statistically significant predictor $(\mathrm{p}<.01)$ of both violent and property crimes separately as well as cumulatively (total crime). Thus, there is consistent evidence that prior year foreclosures exhibit a direct positive effect on current year UCR total, violent, and property crime counts.

\section{Table 6 about here}

Table 7 shows the effects of foreclosures on each individual type of UCR crime. The effect of foreclosures on criminal homicide is not significant, which is not surprising given the small number of cases of homicide. Foreclosures are a significant predictor of rape, but caution should be used in interpreting this result, as it is also based on a smaller number of cases. Foreclosures were not a statistically significant predictor of robberies, but were a significant predictor $(\mathrm{p}<.01)$ of aggravated assault counts. For property crimes, foreclosures were a highly significant predictor of burglaries. Foreclosures did not predict larcenies or vehicle thefts. Thus, aggravated assaults and burglaries appear to be the UCR crimes most related to foreclosures.

\section{Table 7 about here}

\section{Interaction Effects with Disadvantage and Stability}

Recall that we also argued that the effect of foreclosures on crime may vary across neighborhoods (see Harris, 2011). Table 8 shows the results of models that examine the interaction of foreclosures and neighborhood characteristics—specifically our disadvantage and stability indices— 
in predicting total crime. The first model includes no interaction terms for comparison. The second model includes the interaction of the indices of neighborhood disadvantage and stability with the lag $\log$ foreclosure listing measure. These results are in the first two columns of Table 8. The interaction term for disadvantage with foreclosures is not significant but the coefficient for the interaction term for stability with foreclosures is positive and significant. This significant interaction term means that the effect of foreclosures on crime is greater in neighborhoods with higher levels of stability. The stability index incorporates three variables, percent of owner occupied housing units, percent of persons foreign-born, and percent of persons living in the same residence five years ago. The final model includes the interactions of foreclosures with these three variables. The interaction term for percent-owner occupied with foreclosures is significant and positive. The other two interaction terms are not significant. Thus, the conditional effect of neighborhood stability on foreclosures and crime appears to operate through the percentages of owner occupied housing units. It could be that in cells where greater instability is already present, foreclosures may have less of an effect. Housing may be viewed as less of an asset in less stable neighborhoods. Or it could be that high foreclosure neighborhoods that were previously less transient are now experiencing a level of transition that may not have occurred otherwise. Therefore, those previously stable neighborhoods are experiencing a greater expectation of crimes as the number of foreclosures increases.

Table 8 about here

Checks for Robustness

Allison and Waterman (2002) identified potential problems with the Hausman, Hall, and Griliches (1984) procedure used by Stata to estimate FENB models in the current study. No alternative has been shown to be conclusively superior to that method. However, given the potential problems associated with the Stata procedure, we examined alternative means of estimation as a test of the robustness of the Stata FENB results, which are summarized in Table 9. The first base model 
is the FENB model estimated using Stata (Table 6, total crime model). The second model in Table 9 is a standard pooled cross-sectional model that was estimated using the standard negative binomial regression procedure in Stata. To control for other grid cell characteristics that might be associated with the dependent variable, we included: grid cell population, percent African-American, percent Hispanic, the disadvantage index, and the stability index, as controls. Because the cases are repeated each year, robust standard errors are calculated, clustering on the case ID. The lag of the log of neighborhood foreclosure listings is significant in the pooled cross-sectional model. The regression coefficient is larger than in the base model, which may be because the other variables in the model are not fully controlling for the effects of other neighborhood characteristics on crime.

Table 9 about here

Cameron and Trivedi (2010, p. 641) suggest that since Poisson panel estimators rely on weaker distributional assumptions, it may be preferable to estimate negative binomial panel models using the Poisson procedure, obtaining robust standard errors. With the Poisson fixed effects model, Stata provides a bootstrap procedure for obtaining the robust standard errors. As shown in the third model in Table 9, the foreclosure variable is positive and significant $(\mathrm{p}<.01)$ in the Poisson fixed effects model as well. For the final model, Ellen et al.(2011) use what they call a hybrid approach to estimate the FENB model following Allison (2005). They describe this estimation procedure in an appendix as follows: “...we transform the log-linear conditional mean function into mean-deviated form. Instead of the entity dummy and time variables, the D matrix now includes the independent variables in the form of deviations from the entity means and both the entity means, and the precinct*quarter dummy variables are entered into the model.”

To implement this approach, we calculated the means of the lag of log of neighborhood foreclosures across years and then calculated the deviations of the lagged values from these means. These were then used as predictors of total crime, with the model estimated using the Stata negative 
binomial regression procedure. Robust standard errors were obtained, clustering on the case ID. The results are shown as the fourth model in Table 9. The deviation of lag of log foreclosures from the mean is also a statistically significant predictor of crime $(\mathrm{p}<.01)$. All three of the alternative models show a significant effect of the lag of the log of neighborhood foreclosure listings on total crime. These results generally lead to the same substantive conclusions regarding the effects of foreclosures on crime using the FENB procedure as implemented in Stata. Therefore, it appears that the effect of prior foreclosures on crime is robust to model specification, within the limits of available estimation techniques.

\section{DISCUSSION AND CONCLUSIONS}

Although neighborhood instability has long been thought to be associated with higher crime, until very recently the effect of home foreclosures on crime has not been the subject of much research. Several recent studies have examined foreclosures and crime. To date, however, most have been either cross-sectional or conducted on relatively large units of analysis such as counties or MSAs and studies have shown conflicting results (cf. Ellen et al., 2011; Kirk \& Hyra, 2011). Only a few panel studies have been conducted at the intra-city level and only two employ units of analysis smaller than census tracts or police beats. In the current study we examined the relationship between foreclosures and crime counts in Indianapolis from 2003 to 2008 using fixed effects negative binomial models.

Results of the current study showed that both current and prior year foreclosure listings were consistently associated with crime counts. Prior year foreclosure listings appeared to exhibit a somewhat stronger effect on crime. In addition, we examined whether the effects of foreclosures on crime varied across neighborhoods. Somewhat counter to our expectations, the level of socioeconomic disadvantage in the cell did not condition the effect of foreclosures on crime counts. Neighborhood stability, however, conditioned the effect of foreclosures on crime. Both the overall stability index and one component of that index — the owner-occupied home variable-were 
significant. Previous studies have shown that neighborhood instability is related to negative outcomes, such as decreased property values. The conditional positive relationship of foreclosures and neighborhood stability on crime found in this study suggests that foreclosures may add instability to an otherwise relatively more stable neighborhood. Such findings, while preliminary and limited to the geography studied here, may indicate that the recent housing crisis may alert policymakers to a new condition of instability. Although potentially not as strong as other commonly used measures of neighborhood instability, the rise in foreclosures may add a new dimension that justifiably leads to collective action. The federal Neighborhood Stabilization Program is one example of the acknowledgement that collective action to remediate negative outcomes of foreclosures in the least stable neighborhoods may be warranted.

This study is not without its limitations. First, the study is based on one city. Although there is no reason to believe that Indianapolis is atypical with respect to foreclosures or crime, this is an empirical question. Therefore, future studies should test these propositions using small units of analysis in other cities. This study also relies on reported crime data. It is possible that reporting of data varies across neighborhoods. If so, one might imagine that areas with higher foreclosures would be less likely to report crime. If true, this could bias the results of the current study. The net effect however, would likely be that such bias would artificially dampen the relationship between foreclosures and crime. We also acknowledge that the FENB model estimation technique reflected in the Stata package is not a true fixed effects model. We estimated several alternative models which all produced substantively similar results. In every case, foreclosures were a significant positive predictor of crime. Because there is no widely-accepted alternative approach that is clearly superior to the one we chose, we believe that, given the available statistical techniques and evidence, the results described here are robust. We believe that this study contributes to what is likely to become a growing area of research in criminology. 
Table 1. Basic descriptive statistics $(n=11,712)$

\begin{tabular}{lrrrr}
\hline Variable & Mean & \multicolumn{1}{c}{ Minimum } & Maximum & Std. Dev. \\
\hline Total crimes & 18.03 & 0 & 270 & 20.68 \\
Violent crimes & 6.68 & 0 & 107 & 9.18 \\
Property crimes & 11.34 & 0 & 249 & 13.34 \\
Criminal homicides & 0.04 & 0 & 7 & 0.24 \\
Rapes & 0.14 & 0 & 20 & 0.47 \\
Robberies & 1.04 & 0 & 27 & 2.12 \\
Aggravated assaults & 5.46 & 0 & 103 & 7.67 \\
Burglaries & 3.29 & 0 & 53 & 3.82 \\
Larcenies & 6.18 & 0 & 244 & 9.83 \\
Vehicle thefts & 1.88 & 0 & 21 & 2.40 \\
\hline Foreclosure listings & 1.43 & 0 & 47 & 2.21 \\
Foreclosure sales & 0.81 & 0 & 22 & 1.33 \\
\hline Population & 155.00 & 1 & 763 & 111.04 \\
Percent African-American & 39.81 & 0.00 & 100.00 & 37.14 \\
Percent Hispanic & 3.88 & 0.00 & 54.41 & 5.75 \\
Percent female householder & 39.49 & 0.00 & 100.00 & 20.45 \\
with children & & & & \\
Percent owner-occupied & 58.72 & 0.00 & 100.00 & 24.14 \\
Percent foreign-born & 3.70 & 0.00 & 47.97 & 4.68 \\
Percent persons living in same & 51.12 & 0.00 & 100.00 & 13.44 \\
residence five years ago & & & & \\
Percent unemployed & 9.24 & 0.00 & 36.90 & 6.01 \\
Percent below poverty level & 19.24 & 0.00 & 63.98 & 11.78 \\
Median household income & 33,694 & 2,499 & 124,822 & 13,594 \\
\hline & & & & \\
\hline
\end{tabular}

Table 2. Total crimes and foreclosure listings by year

\begin{tabular}{lcccc}
\hline & Mean & Min & Max & Std. Dev. \\
\hline Total crimes & & & & \\
2003 & 16.50 & 0 & 165 & 18.62 \\
2004 & 17.38 & 0 & 197 & 19.96 \\
2005 & 18.29 & 0 & 250 & 21.75 \\
2006 & 18.97 & 0 & 228 & 21.93 \\
2007 & 19.17 & 0 & 270 & 21.80 \\
2008 & 17.84 & 0 & 226 & 19.68 \\
\hline Foreclosure listings & & & & \\
2003 & 0.86 & 0 & 14 & 1.51 \\
2004 & 1.16 & 0 & 12 & 1.84 \\
2005 & 1.37 & 0 & 18 & 2.02 \\
2006 & 1.59 & 0 & 31 & 2.33 \\
2007 & 1.86 & 0 & 47 & 2.77 \\
2008 & 1.73 & 0 & 22 & 2.40 \\
\hline
\end{tabular}


Table 3. Mean number of total crimes by number of foreclosure listings

\begin{tabular}{lrr}
\hline $\begin{array}{l}\text { Number of } \\
\text { foreclosure } \\
\text { listings }\end{array}$ & $\begin{array}{c}\text { Number of } \\
\text { observations }\end{array}$ & $\begin{array}{l}\text { Mean number } \\
\text { of total crimes }\end{array}$ \\
\hline 0 & 5,967 & 12.83 \\
1 & 1,962 & 17.99 \\
2 & 1,277 & 20.15 \\
3 & 850 & 25.14 \\
4 & 570 & 26.37 \\
5 & 366 & 31.17 \\
6 & 283 & 32.14 \\
7 & 169 & 34.99 \\
8 & 85 & 36.58 \\
9 & 68 & 41.69 \\
10 or more & 115 & 41.77 \\
\hline
\end{tabular}

Table 4. Examination of endogeneity using lagged regressions

\begin{tabular}{|c|c|c|}
\hline \multirow[t]{2}{*}{ Independent variables } & \multicolumn{2}{|c|}{ Dependent variable } \\
\hline & $\begin{array}{c}\text { Total number of } \\
\text { crimes }\end{array}$ & $\begin{array}{l}\text { Number of } \\
\text { foreclosure } \\
\text { listings }\end{array}$ \\
\hline Lagged foreclosure listings & $\begin{array}{r}0.00708^{* * *} \\
(0.00238)\end{array}$ & -- \\
\hline Lagged total crimes & -- & $\begin{array}{r}0.000218 \\
(0.00129)\end{array}$ \\
\hline Year 2005 & $\begin{array}{r}0.0377 * * * \\
(0.0111)\end{array}$ & $\begin{array}{r}0.169 * * * \\
(0.0308)\end{array}$ \\
\hline Year 2006 & $\begin{array}{r}0.0780 * * * \\
(0.0110)\end{array}$ & $\begin{array}{r}0.312 * * * \\
(0.0301)\end{array}$ \\
\hline Year 2007 & $\begin{array}{r}0.0951^{* * * *} \\
(0.0111)\end{array}$ & $\begin{array}{r}0.467 * * * \\
(0.0295)\end{array}$ \\
\hline Year 2008 & $\begin{array}{r}0.0302 * * * \\
(0.0115)\end{array}$ & $\begin{array}{r}0.401 * * * \\
(0.0299)\end{array}$ \\
\hline Constant & $\begin{array}{r}3.187 * * * \\
(0.0443) \\
\end{array}$ & $\begin{array}{r}2.786 * * * \\
(0.186) \\
\end{array}$ \\
\hline Observations & 9,370 & 6,885 \\
\hline Number of case id & 1,874 & 1,377 \\
\hline Wald chi-squared & $117.43 * * *$ & $334.48 * * *$ \\
\hline
\end{tabular}


Table 5. Predicting total crime using current and lagged foreclosures

\begin{tabular}{|c|c|c|c|}
\hline Independent variables & $\begin{array}{l}\text { Current } \\
\text { foreclosures }\end{array}$ & $\begin{array}{l}\text { Lagged } \\
\text { foreclosures }\end{array}$ & $\begin{array}{l}\text { Current and } \\
\text { lagged } \\
\text { foreclosures }\end{array}$ \\
\hline Log neighborhood foreclosure listings & $\begin{array}{l}0.0218^{*} \\
(0.0112)\end{array}$ & -- & $\begin{array}{r}0.0145 \\
(0.0113)\end{array}$ \\
\hline $\begin{array}{l}\text { Lag of log of neighborhood foreclosure } \\
\text { listings }\end{array}$ & -- & $\begin{array}{r}0.0475^{* * * *} \\
(0.0111)\end{array}$ & $\begin{array}{r}0.0453 * * * \\
(0.0112)\end{array}$ \\
\hline Year 2005 & $\begin{array}{r}0.0372^{* * *} \\
(0.0112)\end{array}$ & $\begin{array}{r}0.0285^{* *} \\
(0.0114)\end{array}$ & $\begin{array}{r}0.0268 * * \\
(0.0115)\end{array}$ \\
\hline Year 2006 & $\begin{array}{r}0.0765^{* * * *} \\
(0.0114)\end{array}$ & $\begin{array}{r}0.0629 * * * \\
(0.0119)\end{array}$ & $\begin{array}{r}0.0597 * * * \\
(0.0121)\end{array}$ \\
\hline Year 2007 & $\begin{array}{r}0.0925^{* * *} \\
(0.0119)\end{array}$ & $\begin{array}{r}0.0755^{* * *} \\
(0.0125)\end{array}$ & $\begin{array}{r}0.0706 * * * \\
(0.0131)\end{array}$ \\
\hline Year 2008 & $\begin{array}{r}0.0314^{* * *} \\
(0.0118)\end{array}$ & $\begin{array}{r}0.00697 \\
(0.0134)\end{array}$ & $\begin{array}{r}0.00296 \\
(0.0138)\end{array}$ \\
\hline Constant & $\begin{array}{r}3.140 * * * \\
(0.0532)\end{array}$ & $\begin{array}{r}3.089 * * * \\
(0.0512) \\
\end{array}$ & $\begin{array}{r}3.056 * * * \\
(0.0572)\end{array}$ \\
\hline Observations & 9,370 & 9,370 & 9,370 \\
\hline Number of cases & 1,874 & 1,874 & 1,874 \\
\hline Wald chi-squared & $112.08 * * *$ & $126.47 * * *$ & $127.91 * * *$ \\
\hline
\end{tabular}

Standard errors in parentheses

*** $\mathrm{p}<0.01, * * \mathrm{p}<0.05, * \mathrm{p}<0.1$

Table 6. Effects of foreclosures on total crime, violent crime, and property crime

\begin{tabular}{lrrr}
\hline Independent variable & \multicolumn{2}{c}{ Dependent variable } \\
\cline { 2 - 4 } & Total crime & Violent crime & \multicolumn{1}{c}{$\begin{array}{c}\text { Property } \\
\text { crime }\end{array}$} \\
\hline Lag of log of neighborhood foreclosure & $0.0475^{* * *}$ & $0.0621^{* * *}$ & $0.0372^{* * *}$ \\
listings & $(0.0111)$ & $(0.0171)$ & $(0.0130)$ \\
Year 2005 & $0.0285^{* *}$ & $0.0606^{* * *}$ & 0.0146 \\
& $(0.0114)$ & $(0.0169)$ & $(0.0138)$ \\
Year 2006 & $0.0629^{* * *}$ & 0.0285 & $0.0886^{* * *}$ \\
& $(0.0119)$ & $(0.0179)$ & $(0.0142)$ \\
Year 2007 & $0.0755^{* * *}$ & $0.0612^{* * *}$ & $0.0895^{* * *}$ \\
& $(0.0125)$ & $(0.0188)$ & $(0.0149)$ \\
Year 2008 & 0.00697 & 0.00162 & 0.0123 \\
& $(0.0134)$ & $(0.0203)$ & $(0.0160)$ \\
Constant & $3.089^{* * *}$ & $2.717 * * *$ & $2.794^{* * *}$ \\
& $(0.0512)$ & $(0.0736)$ & $(0.0556)$ \\
\hline Observations & 9370 & 9030 & 9325 \\
Number of cases & 1874 & 1806 & 1865 \\
\hline Wald chi-squared & $126.47^{* * *}$ & $53.78^{* * *}$ & $121.03^{* * *}$ \\
\hline
\end{tabular}

Standard errors in parentheses

*** $\mathrm{p}<0.01,{ }^{* *} \mathrm{p}<0.05,{ }^{*} \mathrm{p}<0.1$ 
Table 7. Effects of foreclosures by type of crime

\begin{tabular}{|c|c|c|c|c|c|c|c|}
\hline \multirow[t]{2}{*}{$\begin{array}{l}\text { Independent } \\
\text { variable }\end{array}$} & \multicolumn{7}{|c|}{ Dependent variable } \\
\hline & Homicide & Rape & Robbery & $\begin{array}{l}\text { Agg } \\
\text { Assault }\end{array}$ & Burglary & Larceny & $\begin{array}{l}\text { Vehicle } \\
\text { theft }\end{array}$ \\
\hline $\begin{array}{l}\text { Lag Log } \\
\text { neighbor } \\
\text { Foreclosure } \\
\text { listings }\end{array}$ & $\begin{array}{l}0.234 \\
(0.175)\end{array}$ & $\begin{array}{l}0.272 * * * \\
(0.0930)\end{array}$ & $\begin{array}{l}0.0140 \\
(0.0368)\end{array}$ & $\begin{array}{l}0.0631 * * * \\
(0.0189)\end{array}$ & $\begin{array}{l}0.0622 * * * \\
(0.0222)\end{array}$ & $\begin{array}{l}0.0238 \\
(0.0164)\end{array}$ & $\begin{array}{l}0.0421 \\
(0.0269)\end{array}$ \\
\hline Year 2005 & $\begin{array}{l}-0.0825 \\
(0.171)\end{array}$ & $\begin{array}{l}-0.0785 \\
(0.0892)\end{array}$ & $\begin{array}{l}0.155^{* * *} \\
(0.0381)\end{array}$ & $\begin{array}{l}0.0539 * * * \\
(0.0185)\end{array}$ & $\begin{array}{l}-0.0682 * * * \\
(0.0235)\end{array}$ & $\begin{array}{l}0.0636 * * * \\
(0.0179)\end{array}$ & $\begin{array}{l}0.0553 * * \\
(0.0270)\end{array}$ \\
\hline Year 2006 & $\begin{array}{l}0.00937 \\
(0.175)\end{array}$ & $\begin{array}{l}-0.130 \\
(0.0943)\end{array}$ & $\begin{array}{l}0.154 * * * \\
(0.0395)\end{array}$ & $\begin{array}{l}0.0145 \\
(0.0196)\end{array}$ & $\begin{array}{l}0.0122 \\
(0.0241)\end{array}$ & $\begin{array}{l}0.168 * * * \\
(0.0182)\end{array}$ & $\begin{array}{l}0.000772 \\
(0.0287)\end{array}$ \\
\hline Year 2007 & $\begin{array}{l}-0.117 \\
(0.187)\end{array}$ & $\begin{array}{l}-0.182 * \\
(0.100)\end{array}$ & $\begin{array}{l}0.292 * * * \\
(0.0410)\end{array}$ & $\begin{array}{l}0.0298 \\
(0.0206)\end{array}$ & $\begin{array}{l}0.0357 \\
(0.0254)\end{array}$ & $\begin{array}{l}0.101^{* * * *} \\
(0.0194)\end{array}$ & $\begin{array}{l}0.155^{* * *} \\
(0.0293)\end{array}$ \\
\hline Year 2008 & $\begin{array}{l}-0.241 \\
(0.203)\end{array}$ & $\begin{array}{l}-0.373^{* * *} \\
(0.112)\end{array}$ & $\begin{array}{l}0.255^{* * *} \\
(0.0439)\end{array}$ & $\begin{array}{l}-0.0307 \\
(0.0223)\end{array}$ & $\begin{array}{l}0.0305 \\
(0.0270)\end{array}$ & $\begin{array}{l}0.0130 \\
(0.0209)\end{array}$ & $\begin{array}{l}-0.0493 \\
(0.0324)\end{array}$ \\
\hline Constant & $\begin{array}{l}-0.825 \\
(0.564) \\
\end{array}$ & $\begin{array}{l}1.253 * * * \\
(0.401)\end{array}$ & $\begin{array}{l}2.307 * * * \\
(0.181) \\
\end{array}$ & $\begin{array}{l}2.556 * * * \\
(0.0777) \\
\end{array}$ & $\begin{array}{l}1.942 * * * \\
(0.0784)\end{array}$ & $\begin{array}{l}2.506 * * * \\
(0.0668) \\
\end{array}$ & $\begin{array}{l}2.512^{* * *} \\
(0.138)\end{array}$ \\
\hline Observations & 1,440 & 3,635 & 7,055 & 8,895 & 9,010 & 9,235 & 8,725 \\
\hline $\mathrm{N}$ of crimes & 288 & 727 & 1,411 & 1,779 & 1,802 & 1,847 & 1,745 \\
\hline $\begin{array}{l}\text { Wald chi- } \\
\text { squared }\end{array}$ & 3.12 & $13.89 * *$ & $85.35^{* * *}$ & $36.07 * * *$ & $52.14 * * *$ & $140.73 * * *$ & $83.19 * * *$ \\
\hline
\end{tabular}

Standard errors in parentheses

*** $\mathrm{p}<0.01, * * \mathrm{p}<0.05,{ }^{*} \mathrm{p}<0.1$ 
Table 8 - Interaction of foreclosures with neighborhood disadvantage and stability predicting total crime

\begin{tabular}{|c|c|c|c|}
\hline Independent variables & $\begin{array}{l}\text { Model without } \\
\text { interaction terms }\end{array}$ & $\begin{array}{l}\text { Interactions with } \\
\text { disorganization } \\
\text { and stability }\end{array}$ & $\begin{array}{l}\text { Interactions with } \\
\text { components of } \\
\text { stability }\end{array}$ \\
\hline Lag log neighborhood foreclosure listings & $\begin{array}{r}0.0475^{* * *} \\
(0.0111)\end{array}$ & $\begin{array}{r}0.0520^{* * *} \\
(0.0111)\end{array}$ & $\begin{array}{r}-0.0637^{*} \\
(0.0364)\end{array}$ \\
\hline $\begin{array}{l}\text { Disadvantage * lag log neighborhood } \\
\text { foreclosure listings }\end{array}$ & -- & $\begin{array}{r}-0.000048 \\
(0.00876)\end{array}$ & -- \\
\hline $\begin{array}{l}\text { Stability * lag log neighborhood foreclosure } \\
\text { listings }\end{array}$ & -- & $\begin{array}{r}0.0260 * * * \\
(0.00869)\end{array}$ & -- \\
\hline $\begin{array}{l}\text { Percent owner-occupied * lag log } \\
\text { neighborhood foreclosure listings }\end{array}$ & -- & -- & $\begin{array}{r}0.00113^{* * *} \\
(0.000397)\end{array}$ \\
\hline $\begin{array}{l}\text { Percent foreign-born * lag log neighborhood } \\
\text { foreclosure listings }\end{array}$ & -- & -- & $\begin{array}{r}0.00180 \\
(0.00160)\end{array}$ \\
\hline $\begin{array}{l}\text { Percent living same residence five years ago } \\
* \text { lag log neighborhood foreclosure listings }\end{array}$ & -- & -- & $\begin{array}{r}0.000879 \\
(0.000746)\end{array}$ \\
\hline Year 2005 & $\begin{array}{r}0.0285^{* *} \\
(0.0114)\end{array}$ & $\begin{array}{r}0.0263^{* *} \\
(0.0114)\end{array}$ & $\begin{array}{r}0.0265^{* *} \\
(0.0114)\end{array}$ \\
\hline Year 2006 & $\begin{array}{r}0.0629 * * * \\
(0.0119)\end{array}$ & $\begin{array}{r}0.0612^{* * *} \\
(0.0119)\end{array}$ & $\begin{array}{r}0.0599 * * * \\
(0.0119)\end{array}$ \\
\hline Year 2007 & $\begin{array}{r}0.0755^{* * *} \\
(0.0125)\end{array}$ & $\begin{array}{r}0.0745^{* * *} \\
(0.0125)\end{array}$ & $\begin{array}{r}0.0734^{* * *} \\
(0.0125)\end{array}$ \\
\hline Year 2008 & $\begin{array}{r}0.00697 \\
(0.0134)\end{array}$ & $\begin{array}{r}0.00638 \\
(0.0134)\end{array}$ & $\begin{array}{l}0.00634 \\
(0.0134)\end{array}$ \\
\hline Constant & $\begin{array}{r}3.089 * * * \\
(0.0512)\end{array}$ & $\begin{array}{r}3.103^{* * *} \\
(0.0523)\end{array}$ & $\begin{array}{r}3.112 * * * \\
(0.0518)\end{array}$ \\
\hline Observations & 9,370 & 9,360 & 9,370 \\
\hline Number of caseid & 1,874 & 1,872 & 1,874 \\
\hline Wald chi-squared & $126.47^{* * *}$ & $137.23^{* * *}$ & $145.55^{* * *}$ \\
\hline
\end{tabular}

Standard errors in parentheses

${ }^{* * *} \mathrm{p}<0.01,{ }^{* *} \mathrm{p}<0.05,{ }^{*} \mathrm{p}<0.1$ 
Table 9. Alternative models predicting total crime as test of robustness

\begin{tabular}{|c|c|c|c|c|}
\hline Independent variables & $\begin{array}{l}\text { Model estimated } \\
\text { using Stata } \\
\text { negative binomial } \\
\text { fixed effects } \\
\text { procedure }\end{array}$ & $\begin{array}{c}\text { Pooled cross- } \\
\text { sectional model } \\
\text { estimated using } \\
\text { negative binomial } \\
\text { procedure with } \\
\text { robust standard } \\
\text { errors }\end{array}$ & $\begin{array}{l}\text { Model estimated } \\
\text { using Stata } \\
\text { Poisson fixed } \\
\text { effects procedure } \\
\text { with bootstrap } \\
\text { standard errors }\end{array}$ & $\begin{array}{c}\text { Model using } \\
\text { Allison/Ellen } \\
\text { procedure } \\
\text { estimated using } \\
\text { negative } \\
\text { binomial } \\
\text { procedure with } \\
\text { robust standard } \\
\text { errors }\end{array}$ \\
\hline $\begin{array}{l}\text { Lag log neighborhood foreclosure } \\
\text { listings }\end{array}$ & $\begin{array}{l}0.0649 * * * \\
(0.00885)\end{array}$ & $\begin{array}{l}0.186 * * * \\
(0.0246)\end{array}$ & $\begin{array}{c}0.0373^{* * *} \\
(0.0143)\end{array}$ & -- \\
\hline $\begin{array}{l}\text { Deviation of lag log foreclosures } \\
\text { from mean across cases }\end{array}$ & -- & -- & -- & $\begin{array}{r}0.0334 * * * \\
(0.0109)\end{array}$ \\
\hline $\begin{array}{l}\text { Mean across cases lag log } \\
\text { neighborhood foreclosure listings }\end{array}$ & -- & -- & -- & $\begin{array}{r}0.361 * * * \\
(0.0352)\end{array}$ \\
\hline Population & -- & $\begin{array}{r}0.00336 * * * \\
(0.000288)\end{array}$ & -- & -- \\
\hline Percent African-American & -- & $\begin{array}{r}-9.41 \mathrm{e}-05 \\
(0.000934)\end{array}$ & -- & -- \\
\hline Percent Hispanic & -- & $\begin{array}{r}0.00436 \\
(0.00431)\end{array}$ & -- & -- \\
\hline Disadvantage index & -- & $\begin{array}{r}0.0960 * * \\
(0.0382)\end{array}$ & -- & -- \\
\hline Stability index & -- & $\begin{array}{r}-0.305^{* * *} \\
(0.0362)\end{array}$ & -- & -- \\
\hline Constant & $\begin{array}{l}3.041 * * * \\
(0.0489)\end{array}$ & $\begin{array}{l}1.784 * * * \\
(0.0732) \\
\end{array}$ & $\begin{array}{l}-0.405 * * * \\
(0.0575)\end{array}$ & $\begin{array}{r}2.077 * * * \\
(0.0951) \\
\end{array}$ \\
\hline $\begin{array}{l}\text { Observations } \\
\text { Number of case id }\end{array}$ & $\begin{array}{l}9,370 \\
1,874\end{array}$ & 9,590 & $\begin{array}{l}9,370 \\
1,874\end{array}$ & 9,760 \\
\hline Wald chi-squared & $53.84 * * *$ & $695.08 * * *$ & $9.07 * * *$ & $111.91^{* * *}$ \\
\hline
\end{tabular}


Map 1. Indianapolis and 1,000 feet Grid Cells

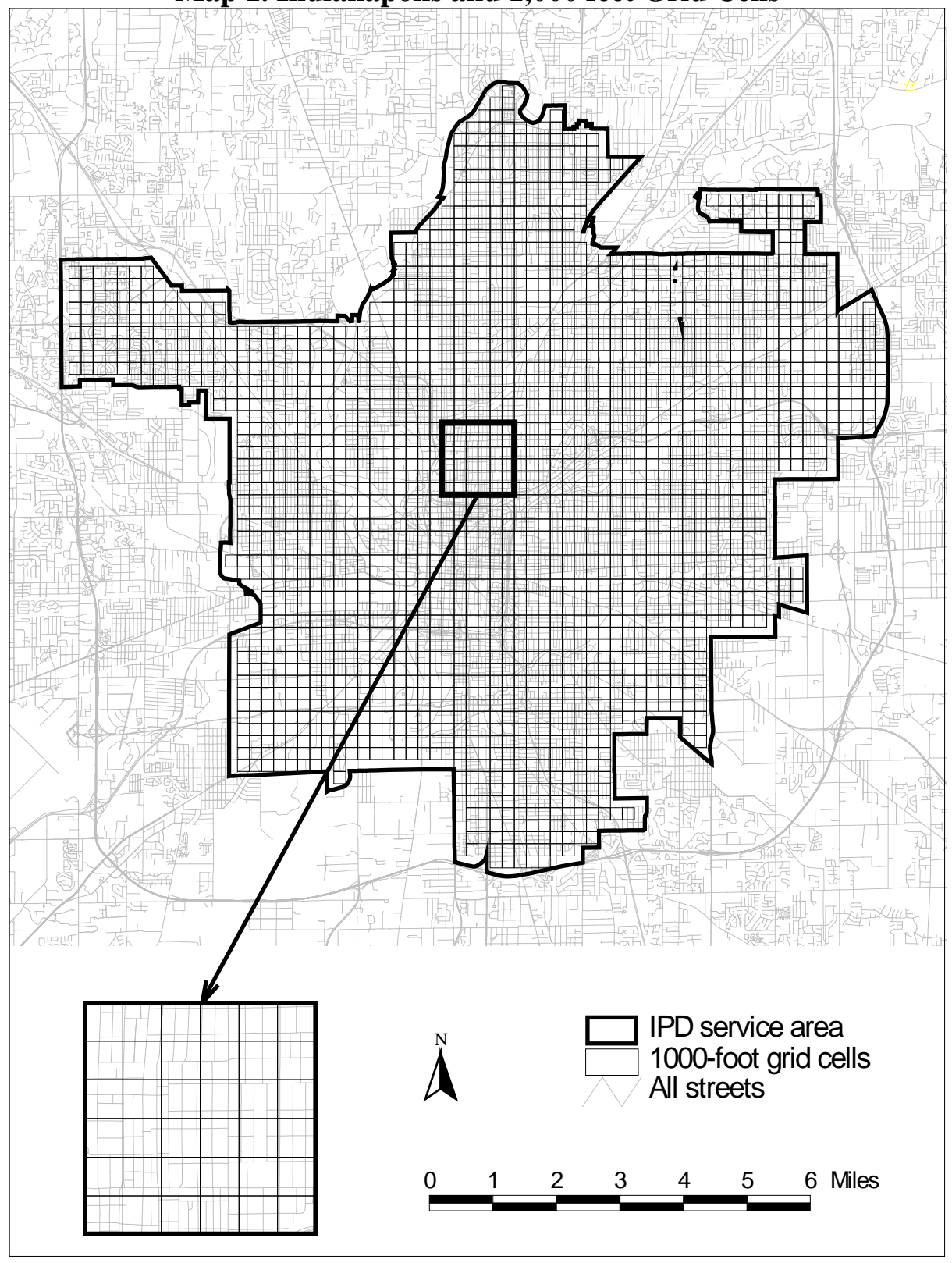




\section{References}

Authors 2009

Acevedo, Luis G. 2009. “An Empirical Analysis of the Impact of Home Foreclosure on the Crime Rate: Evidence in Atlanta, GA.” Research paper, Economics. Smithfield, RI: Bryant University.

Allison, Paul D. 2005. Fixed Effects Regression Methods for Longitudinal Data Using SAS. Cary NC: SAS Institute Inc.

Allison, Paul D., and Richard P. Waterman. 2002. "Fixed-effects Negative Binomial Regression Models.” Sociological Methodology 32: 247-265.

Apgar, William and Mark Duda. 2005. Collateral Damage: The Municipal Impact of Today's Mortgage Foreclosure Boom. Washington, DC: Homeownership Preservation Prevention Foundation.

Baumer, Eric P., Kevin T. Wolff, and Ashley N. Arnio. 2011. "The Contemporary Foreclosure Crisis and U.S. Crime Rates.” Unpublished manuscript, College of Criminology and Criminal Justice. Tallahassee, FL: Florida State University.

Bess, Michael. 2008. “Assessing the Impact of Home Foreclosures in Charlotte Neighborhoods.” Geography and Public Safety 1(3): 2-5.

Cameron, A. Colin, and Pravin K. Trivedi. 1998. Regression Analysis of Count Data. Cambridge, England: Cambridge University Press.

Cameron, A. Colin, and Pravin K. Trivedi. 2010. Microeconometrics Using Stata. College Station TX: Stata Press.

Cohen, Lawrence E., and Marcus Felson. 1979. "Social Change and Crime Rate Trends: A Routine Activity Approach.” American Sociological Review 44: 588-608.

Crawford, Gordon W. and Eric Rosenblatt. 1995. "Efficient Mortgage Default Option Exercise: Evidence from Loss Severity.” Journal of Real Estate Research 10(5): 543-55.

Cui, Lin. 2011. “Foreclosure, Vacancy, and Crime.” Unpublished manuscript. Available at (http://www.pitt.edu/ lic29/Foreclosure, Vacancy and Crime.pdf).

Ellen, Ingrid Gould, Johanna Lacoe, and Claudia Sharygin. 2011. “Do Foreclosures Cause Crime?” Unpublished manuscript. Available at (http://www.frbsf.org/community/conferences/2011ResearchConference/docs/3a-sharyginpaper.pdf).

Goodstein, Ryan M., and Yan Y. Lee. 2010. Do Foreclosures Increase Crime? Federal Deposit Insurance Corporation Center for Financial Research Working Paper, No. 2010-05. Available at (http://www.fdic.gov/bank/analytical/cfr/2010/wp2010/CFR_WP_2010_05goodsteinlee.pdf).

Greene, William H. 2000. Econometric Analysis, $4^{\text {th }}$ edition. Upper Saddle River, NJ: Prentice Hall. 
Harding, John P., Eric Rosenblatt, and Vincent W. Yao. 2009. "The Contagion Effect of Foreclosed Properties.” Journal of Urban Economics 66(3): 164-178.

Harris, Paul E. (Lish). 2011. "The Criminal Consequences of Changes in Neighborhood Structure Due to Home Foreclosure: A Theoretical Discussion.” Chapter in In Economic Crisis and Crime, edited by Mathieu Deflem. Bingley, UK: Emerald.

Hausman, Jerry, Bronwyn H. Hall, and Zvi Griliches. 1984. "Econometric Models for Count Data with an Application to the Patents-R\&D Relationship.” Econometrica 52(4): 908-938.

Hipp, John R., George E. Tita, and Robert T. Greenbaum. 2009. "Drive-bys and Trade-ups: Examining the Directionality of the Crime and Residential Instability Relationship.” Social Forces 87(4): 1777-1812.

Immergluck, Dan and Glenn Smith. 2006a. "The External Costs of Foreclosure: The Impact of Single-Family Mortgage Foreclosures on Property Values.” Housing Policy Debate 17(1): 57-79.

Immergluck, Dan and Geoff Smith. 2006b. "The Impact of Single Family Mortgage Foreclosures on Neighborhood Crime.” Housing Studies, 21(6): 851-866.

Jones, Roderick W., and William A. Pridemore. 2011. "Foreclosure and Crime: The Impact of Housing-mortgage Stress on Violent and Property Crime in US Metropolitan Areas.” Under first review.

Kirk, David, and Derek Hyra. 2011. "Home Foreclosures and Community Crime: Causal or Spurious Association?” Manuscript submitted for publication. Available at (http://ssrn.com/abstract=1697871).

Land, Kenneth C., Patricia L. McCall, and Lawrence E. Cohen. 1990. "Structural Covariates of Homicide Rates: Are There Any Invariances Across Time and Social Space?” American Journal of Sociology 95(4):922-963.

Li, Yanmei, and Hazel A. Morrow-Jones. 2010. "The Impact of residential Mortgage Foreclosure on Neighborhood Change and Succession.” Journal of Planning Education and Research 30(1): 2239.

Lin, Zhenguo, Eric Rossenblatt, and Vincent W. Yao. 2009. "Spillover Effects of Foreclosures on Neighborhood Property Values.” Journal of Real Estate Finance and Economics 38(4): 387-407.

Moreno, Ana. 1995. The Cost-Effectiveness of Mortgage Foreclosure Prevention. Minneapolis: Family Housing Fund.

Osgood, D. Wayne. 2000. “Poisson-based Regression Analysis of Aggregate Crime Rates.” Journal of Quantitative Criminology 16(1): 21-43.

Osgood, D. Wayne, and Jeff M. Chambers. 2000. "Social Disorganization Outside the Metropolis: An Analysis of Rural Youth Violence. Criminology 38(1): 81-115. 
Pandit, Caaminee. 2011. “The Impact of Foreclosures on Crime in American Cities.” Sociological Insight 3: 82-109.

Parker, Karen F., and Patricia L. McCall. 1999. "Structural Conditions and Racial Homicide Patterns: A Look at the Multiple Disadvantages in Urban Areas.” Criminology 37(3): 447-477.

Pennington-Cross, Anthony. 2006. “The Value of Foreclosed Property.” Journal of Real Estate Research 28(2): 193-214.

Sampson, Robert J., and W. Byron Groves. 1989. "Community Structure and Crime: Testing Social Disorganization Theory.” American Journal of Sociology 94(4): 774-802.

Sampson, Robert J., and Stephen W. Raudenbush. 1999. "Systemic Social Observation of Public Spaces: A New Look at Disorder in Urban Neighborhoods.” American Journal of Sociology 105(3): 603-651.

Sampson, Robert J., and Stephen W. Raudenbush. 2004. "Seeing Disorder: Neighborhood Stigma and the Social Construction of ‘Broken Windows'.” Social Psychology Quarterly 67(4): 319342.

Sampson, Robert J., Stephen W. Raudenbush, and Felton Earls. 1997. "Neighborhoods and Violent Crime: A Multilevel Study of Collective Efficacy.” Science 277: 918-924.

Schuetz, Jenny, Vicki Been, and Ingrid Gould Ellen. 2008. "Neighborhood Effects of Concentrated Mortgage Foreclosures.” Journal of Housing Economics 17(4): 306-319.

Shaw, Clifford R. and Henry D. McKay. 1972[1942]. Juvenile Delinquency and Urban Areas. Revised ed. Chicago, IL: The University of Chicago Press.

Spelman, William. 1993. “Abandoned Buildings: Magnets for Crime?” Journal of Criminal Justice 21(5): 481-495.

StataCorp. 2009. Stata Longitudinal-Data/Panel-Data Reference Manual: Release 11. College Station TX: Stata Press.

Teasdale, Brent, Clark, Lynn M., and Joshua C. Hinkle. 2010. "Subprime Lending Foreclosures, Crime, and Neighborhood Disorganization: Beyond Internal Dynamics.” American Journal of Criminal Justice. Accessed at Online First: DOI: 10.1007/s12103-010-9093-z

Wilson, James Q., and George L. Kelling. 1982. "The Police and Neighborhood Safety: Broken Windows.” Atlantic Monthly 127: 29-38.

Xie, Min, and David McDowall. 2008. "The Effects of Residential Turnover on Household Victimization.” Criminology 46(3): 539-575. 